\title{
Author Correction: Strain-induced structure and oxygen transport interactions in epitaxial $\mathrm{La}_{0.6} \mathrm{Sr}_{0.4} \mathrm{CoO}_{3-\delta}$ thin films
}

Yurii P. Ivanov, Markus Kubicek, Matthäus Siebenhofer (D), Alexander Viernstein, Herbert Hutter, Jürgen Fleig (D), Andrey Chuvilin (10) \& Zaoli Zhang

Correction to: Communications Materials https://doi.org/10.1038/s43246-020-0027-0, published online 8 May 2020.

The name of author Zaoli Zhang was incorrectly given as Zaoli L. Zhang in the original version of this Article.

This has now been corrected in HTML and PDF versions of the Article.

Published online: 29 May 2020

(c) (i) Open Access This article is licensed under a Creative Commons Attribution 4.0 International License, which permits use, sharing, adaptation, distribution and reproduction in any medium or format, as long as you give appropriate credit to the original author(s) and the source, provide a link to the Creative Commons license, and indicate if changes were made. The images or other third party material in this article are included in the article's Creative Commons license, unless indicated otherwise in a credit line to the material. If material is not included in the article's Creative Commons license and your intended use is not permitted by statutory regulation or exceeds the permitted use, you will need to obtain permission directly from the copyright holder. To view a copy of this license, visit http://creativecommons.org/licenses/by/4.0/.

(c) The Author(s) 2020 